\title{
TTR
}

Traduction, terminologie, re?daction

\section{Inventing the Past: Remarks on the Re-enactment of Medieval Poetry}

\section{Barbara Folkart}

Volume 11, numéro 1, 1er semestre 1998

Diachronie et synchronie

Diachronics and Synchronics

URI : https://id.erudit.org/iderudit/037314ar

DOI : https://doi.org/10.7202/037314ar

Aller au sommaire du numéro

\section{Éditeur(s)}

Association canadienne de traductologie

ISSN

0835-8443 (imprimé)

1708-2188 (numérique)

Découvrir la revue

Citer cet article

Folkart, B. (1998). Inventing the Past: Remarks on the Re-enactment of Medieval Poetry. TTR, 11(1), 11-32. https://doi.org/10.7202/037314ar
Résumé de l'article

Inventer le passé : remarques sur la réactivation de la poésie médiévale Quelles que puissent être par ailleurs ses compétences de médiéviste, la traductrice de poésie ancienne demeure coupée, radicalement, de la matrice culturelle et pragmatique qui a informé aussi bien la réception que la production de ces textes.

Il existe, bien entendu, toute une panoplie d'approches traductionnelles inadéquates, pour la plupart. La traduction-glose met en évidence le "grain " du texte, ses micro-structures linguistiques, mais passe à côté de ses contenus esthétiques et affectifs, comme de ses résonances culturelles. La traduction en prose fournit une meilleure approximation des contenus immédiats, mais escamote le sens véhiculé par la forme même. Même la traduction en vers peut passer à côté de la poésie du poème. Seule la traduction qui constitue en elle-même un poème aura quelques chances de procurer au lecteur cette jouissance esthétique et affective sans laquelle il n'est pas d'expérience poétique.

Cet essai fait état d'un certain nombre de stratégies artistiques visant à " réactiver ", pour le lecteur du vingtième siècle, quelque chose de la poésie et de la charge affective du poème médiéval. Mes réflexions sont illustrées par un certain nombre de " poèmes dérivés » que j'ai tirés moi-même de l'oeuvre de Charles d'Orléans.
Tous droits réservés @ C TTR: traduction, terminologie, rédaction — Les auteurs, 1998
Ce document est protégé par la loi sur le droit d'auteur. L’utilisation des services d'Érudit (y compris la reproduction) est assujettie à sa politique d'utilisation que vous pouvez consulter en ligne.

https://apropos.erudit.org/fr/usagers/politique-dutilisation/ 


\section{Inventing the Past : Remarks on the Re-enactment of Medieval Poetry}

Barbara Folkart

The past must be invented, the future revised. - John Cage

No matter how qualified she may be from the philological standpoint, the translator of medieval poetry is immediately confronted with a sense of her own diachronic incompetence : she is incapable of "getting inside the poem" the way a contemporary of Charles d'Orléans would have done, for she is cut off, radically, from its cultural and pragmatic matrix. For the translator, as for any other twentieth-century reader, the medieval poem can all too easily remain lettre morte.

The very act of reading an ancient text is to some extent problematic, even for the specialist who has spent the last twenty years of her life in day-to-day contact with classical or medieval texts. Reading is an interaction involving not only the text and the receiver, but also the linguistic and cultural matrices in which both reader and text are embedded. Insofar as the linguistic medium is concemed, we have no access whatsoever to the living, fluctuating, proliferating parole that informed the medieval poet - and his work - every day of his life. The cultural matrix, too, is a rich semiotic web from which we are cut off in all but the most archeological sense : the connotations of social status, the belief- and value-systems with which objects in any culture inevitably 
become invested perish, the semiotics of objects get lost long before the objects themselves. As often as not, our reading has to be mediated by an explanatory apparatus designed to reconstitute the pragmatic connotations that are functionally relevant to the way the text works. A recent editor of Charles d'Orléans feels it necessary to glose the phrase soubz la lune : "pour le moyen âge," he explains, "le monde sublunaire est la partie de P'univers soumise aux changements" (Mühlethaler, 1992, p. 205).

Esthetic codes and expectations also tend to be culture-specific. Twentieth-century poetry no longer derives its pleasures and its effects from the re-deployment of familiar figures; it deals in freshly minted rhymes and images, in insight, rather than allegory and personification.

In short, our interaction with these texts is a highly mediated one. Lacking the esthetic and cultural and emotional competencies of a fifteenth-century reader, we must constantly make allowances. And so it is that the translator operates from a position of deficit. It's difficult for her to experience the jouissance the medieval poem was meant to procure, and even harder to get that jouissance across to the twentieth-century reader.

As always, the difficulties are compounded when one deals with poetic texts. The translation of poetry raises the problem of tradeoffs in a particularly acute way, since the poetic text is a constellation of levels that converge against all odds to resonate more than synergistically. It's virtually impossible to reconstitute such a convergence in another language; as certain levels are prioritized, others will have to be jettisoned. Yet so entrenched is the ideology of "fidelity" that most translators unquestioningly go the mimetic route.

\section{Mimetic strategies}

Even leaving aside variations from one translator to another, there are any number of mimetic strategies, all of them partial, each with its own sphere of validity, its own set of tradeoffs and traps.

The translator who chooses to produce a crib will give the modem reader a way into the denotations and surface structures of the medieval text, but will convey little of its emotional resonance - and will 
need a critical apparatus to give insight into the cultural resonances the text would have aroused in the medieval reader. Cribs are a purely instrumental, "throwaway" form of translation : they exist only to get us into the language system of the text. Once we are into that language system, we can forget about the crib, with its focus on the grain, not the poetry, of the poem. In Jean-Claude Mühlethaler's glose of Orléans's Balade 72, language-focussed "transcodings" such as commej'en avais l'habitude, for comme je souloye, convey "ethnolinguistic" rather than esthetic information :

Balade 72

[...]

Essaier vueil se je sauroye

Rimer ainsi que je souloye.

Au meins j'en feray mon povoir, Combien que je congois et sçay

Que mon langage trouveray

Tout enroillié de nonchaloir.

\section{Mühlethaler's crib}

je veux voir si je saurais encore rimer comme j'en avais l'habitude. Je ferai au moins ce qui est en mon combien que : bien que Ipouvoir je trouverai mon langage tout enrouillé de négligence.

Note especially how nonchaloir - one of the richest and most original entities in the entire corpus - gets reduced to négligence. "Word-to-word" translation is the royal road to inaccuracy.

Opting for prose translation will allow our translator to flesh her reading out somewhat, convey (or perhaps even update) the imagery (Ezra Pound's phanopoeia), but will capture little of the music (melopoiea) and none of the meaning inherent in the form itself (what Pound might have called taxopoeia). Far from giving the modern reader a way into the beauty and emotional impact of the source text, the prose translation, unless it's done by a gifted writer, can easily wind up sounding like something by a third-rate Victorian :

There were yet three nights before the horns of the moon would meet and make the round orb. When the moon shone at her fullest and looked down upon the earth with unbroken shape, Medea went forth from her house clad in flowing robes, barefoot, her hair unadorned and streaming down her shoulders; and all alone she wandered out into the deep stillness of midnight. Men, birds and beasts were sunk in profound repose; there was no sound in the hedgerow; the leaves hung mute and motionless; the dewy air was still. Only the stars twinkled. Stretching 
up her arms to these, she turned thrice about, thrice sprinkled water caught up from a flowing stream upon her head and thrice gave tongue in wailing cries. (Ovid, Metamorphoses, VII, pp. 179 - 192, translated by Frank Justus Miller, Loeb Classical Library)

Ovid in the Loeb Classical Library Series, Chrétien de Troyes in the "Scriptural" syntax and vocabulary of W.W. Comfort, Sir Gauwain and the Green Knight in the mildly old-fashioned cadences of W.R.J. Barron - these prose translations range from the grotesque to the engaging, but none of them have anything like the power of, say, Christopher Logue's Patrocleia.

Even verse renderings can easily fall short of the mark. C.H. Sisson is a much admired poet, but his lumbering translation of $\mathrm{La}$ Fontaine's Contes holds our interest only because the stories themselves are so "dirty". And Richard Wilbur's attempt to make his rendering of Orléans's most celebrated rondel seem "old" leads to grossly inauthentic results :

Le temps a Jaissiê son manteau

De vent, de froidure et de pluye, Et s'est vestu de brouderie

De soleil luyant cler et beau.

Il n'y a beste ne oyseau

Qu'en son jargon ne chante ou crie :

Le temps a laissié son manteau

De vent, de froidure et de pluye.

Riviere, fontaine et ruisseau

Portent, en livree jolie, Gouttes d'argent d'orfaverie : Chascun s'abille de nouveau Le temps a laissié son manteau
The year has cast its cloak away

That was of driving rains and snows, And now in flowered arras goes, And wears the clear sun's glossy ray.

No bird or beast but seems to say In cries or chipper tremolos: The year has cast its cloak away That was of driving rains and snows.

Stream, brook and silver fountain play, And each upon itself bestows A spangled livery as it flows. All creatures are in fresh array. The year has cast its cloak away.

This is precisely the sort of arch diction, outdated imagery and end-stopped tetrameter that Wilbur would never dream of using in a poem of his own. When Richard Wilbur writes in his own voice, this is what it sounds like : 
The Beautiful Changes

One wading a Fall meadow finds on all sides The Queen Anne's Lace lying like lilies On water; it glides

So far from the walker, it turns

Dry grass to a lake, as the slightest shade of you

Valleys my mind in fabulous blue Lucernes.

The beautiful changes as a forest is changed

By a chameleon's tuning his skin to it;

As a mantis, arranged

On a green leaf, grows

Into it, makes the leaf leafier, and proves

Any greenness is deeper than anyone knows.

Your hands hold roses always in a way that says

They are not only yours; the beautiful changes

In such kind ways,

Wishing ever to sunder

Things and things' selves for a second finding, to lose

For a moment all that it touches back to wonder.

Wilbur is a fine poet, but as a translator he's guilty of serving a double standard; this sort of condescension is what I refer to as translating down.

Thus we keep coming up against a fundamental paradox : translation that sets out to be mimetic is almost invariably less than mimetic, in one way or another. Every single one of the strategies I've just enumerated has its own write-offs. To borrow a distinction from the language philosophers, translation whose starting point is also its telos, whose paramount goal and good is to replicate, usually turns out to be a comment, rather than a mention : it tells us (something) about the original poem, rather than forcing us into the raw and radical experience of the poem.

Even more desiccating than the losses incurred through tradeoffs is the loss of impulsion. Vouloir-redire almost always gives less compelling results than vouloir-dire, probably because the desire to replicate is a far less authentic stance and provides a far less potent impulsion than the emotional and esthetic and creative tensions that drove the original poem. (There's a striking analogy to be drawn here with the 
the original poem. (There's a striking analogy to be drawn here with the French classical pianist Jean-Yves Thibaudet attempting to replicate some of jazz great Bill Evans's recorded improvisations ${ }^{1}$.) What comes into play here are issues of impulsion and ownership : my hunch is that where there's less ownership of the text being produced, there's apt to be less delight, in the text and for the reader.

Be that as it may, none of the mimetic strategies (as legitimate as they are within their own, very limited, spheres of validity) can give the reader anything like the insight through feeling, and the sheer jouissance, that poetry should procure.

\section{Reactivation and Re-enactment}

Now the translator may consider that it's not worth getting across one or more of the lower levels of the poem-system, if esthetic and emotional impact have to be sacrificed. She may choose to privilege jouissance over low-level accuracy. Which is why it's useful to be able to consider translation as a non-mimetic practice, as writing rather than re-writing. To put it another way (if you insist on envisaging translation in terms of "trade-offs" and "equivalences"), the translator's strategy can be to trade all the rest off against poetic impact - not necessarily the impact produced by the source-text, but an impact. She can decide to jettison whatever interferes with the target text's status as poetry (which is why, in an earlier publication, I've spoken of "The poem as unit of translation"). What gets written off here is the constraint of mimesis.

' In preparation of his recent $\mathrm{CD}$, "Conversations with Bill Evans", Thibaudet hired a music consultant to transcribe, note for note, some of Evan's recorded improvisations. Thibaudet then recorded the "improvisations" from the "scores". Not surprisingly, the result just ain't got that swing. Question of impulsion : it's one thing to feel your way through the improvisation that's coming out of your fingers in response to whatever instant you're at, quite another to reproduce. Improvisation is a rule-constrained activity, not a pure flight of fancy, but there's something grotesque about the idea of repeating an improvisation - as if it were possible to pre-script spontaneity, and pre-define creativity. 
The translator's goal is now to write a poem out of the way she has experienced the source-text ${ }^{2}$ - to produce a target-time, target-space poem that really is a poem, one that re-enacts the jouissance rather than merely commenting on the way it may have been produced for the medieval reader. (This, of course, presupposes that the translator has the requisite talent and technique - but then, every form of specialized translation makes its own specialized demands : you can't do scientific or legal translation without having the appropriate background.) The resulting poem will fall somewhere along the metatextual continuum that stretches from "perfect replication" to "free" creation. It should give the twentieth-century reader a way into the poetry of the original, as opposed to its syntax and bare semantics. The end product should be something that the modern reader can respond to au premier degré and not have to "make allowances for".

Inevitably, reactivation will involve making the medieval poem new for the twentieth-century reader. Not by merely falling back on the "exoticism" of the ancient; rather by finding a way to pull the text out of the realm of the already-said, to put it into direct contact with us and with the world around us (after all, the world that confronts us day to day is never an already-said, if we know how to live with any degree of receptivity and intelligence).

Admittedly, if I can allow myself a digression on inter-semiotic translation, some art forms seem to require less "making new" than others. Of considerable interest from the theoretical point of view is the fact that different semiotic systems seem to obsolesce at different rates : medieval music and painting can retain their freshness where words have sometimes lost their power to move us - Claude Lejeune's "metred" settings of Antoine Baillif still take the top of my head off. I would guess that the rate at which a serniotic system ages might well be proportional to its instrumentality : verbal language ages fastest because it has a primarily instrumental vocation. Literature is play - in other words, a subversion of language's instrumental vocation; but the language (the idiom) which is its raw material ages all the more rapidly that it is in

\footnotetext{
${ }^{2}$ What the poet Jacques Brault (Brault, 1977, p. xx) has termed "un poème relatif à une expérience de lecture".
} 
constant use in everybody's mouth. All idioms age - no one in the twentieth century would dream of composing in the manner of Lejeune - but the musical idiom, in this case, has retained far more power over us than the verbal idiom.

Particularly interesting from the standpoint of their non-obsolescence are mixed genres such as opera, or the art song, involving two or more interacting semiotics. Baroque opera has the power to reactivate a sense of out-of-control passion that no longer comes across in classical tragedy. If one compares, for example, Act III of Jean-Philippe Rameau's Hippolyte et Aricie with Acte I, scene 3 of Racine's Phèdre, Phèdre's tirade (Un trouble s'éleva dans mon âme éperche... Je sentis tout mon corps et transir et bruler), with its classical diction and interminable end-stopped alexandrins comes out the loser. Rameau's opera has the force of semiotic systems resonating in synergy, the whole greater than the sum of its parts. Just how this resonance is achieved is an area which is only now starting to be explored, in the case of the art song, for example. And the way in which interaction between words and music (not to mention stage settings, costumes, acting styles and the like) affects the extent to which an art form retains its freshness is certainly an area of considerable potential interest.

To get back to the translation of ancient poetry, making new is a corollary of what I've referred to elsewhere (Folkart, forthcoming) as restless semiosis. Poetic creation makes ruthless demands, in the name of authenticity. The already-said is never good enough, and Richard Wilbur's wannabe-archaic diction is parole vide - esthetically counter-productive because it undercuts the celebratory freshness of the poem it is supposed to serve. In order to arrive at authentic truths, we need to get rid of the esthetic and cognitive templates that interfere with perception. Ezra Pound was right : artists are indeed in the business of "making it new" - not for the sake of newness, but for the sake of stirring us to feeling and insight.

Semiosis is a particularly relentless process in the poetic domain : strategies and techniques must constantly be renewed if they are to retain any power over us. "Re-semiosis" creates cultural obsolescence by turning once potent devices into old chestnuts. Off-the-peg imagery leaves us cold, allegories strike us as impoverished stick-figures. 
Outmoded dictions, worn-down rhetorical strategies, burnt-out emotional stances, conventional imagery - how to reactivate them so they become emotionally viable rather than just historically or philologically accurate? Add to this the fact that as poetry goes on being written, century after century, certain forms become improductive. The villanelle has been revitalized by poets like Dylan Thomas, but forms like the triolet get stigmatized as trivial or pedantic. In other words, every poetic form carries with it a set of cultural connotations to be exploited or overcome : just imagine trying to write an elegy in limerick stanzas!

Poetic themes, too, decay into cliches, once the original impulsion has gone out of them. Thirty years ago, when the American poet Anne Sexton was the first to write about menstruation, she was working out of a genuine impulsion. Now, menstruation is de rigueur, in certain North American reviews (a small Prairie publication recently organized a contest for poetry about menstruation : one wonders how the efforts of these sheep-like poetesses measured up to the work of a path-blazer like Sexton). To anticipate my translations of Charles d'Orléans, the topos of the death of the poet's lady was one I had difficulty reactivating with any degree of conviction.

At an even more fundamental level, there can be mismatches between the emotional pitches at which different poetries operate : as the Canadian poet and translator A. F. Moritz has pointed out, the coolly ironic stance of much contemporary Anglo-American poetry makes it difficult to render into English the intense affectivity, the passionate and emphatic diction of a Chilean poet like Ludwig Zeller. Insofar as medieval poetry is concerned, all those intervening centuries of poetic practise add up to a sea-change in esthetic expectations. The question, for the translator whose prime concern is to make the medieval poem come alive, remains : What has the translator got to do in order to take the top off the twentieth-century reader's head?

Pretty much what the twentieth-century poet has to do : put us into unmediated contact with the instant. The twentieth century likes its poetry concrete, particular, "true to its occasion" (Thom Gunn). We expect poetry to use the concrete and the particular as privileged points of entry into the abstract and the universal. It's instant by instant, after all, that the eternal comes to us. 
Let me give you an example. In the middle of a particularly disconnected sonnet, Seamus Heaney writes :

\author{
Do you remember that pension in Les Landes \\ Where the old one sat and rocked and rocked and rocked \\ A mongol in her lap, to little songs? \\ (Glanmore Sonnet VIII, in Heaney, 1990, p. 116).
}

In twenty-seven words and an image, Heaney has made us feel what humanness consists of, and what it does not consist of. He's forced us into direct contact with a type of grief and a type of love which no discourse has ever exhausted. The real will always offer an un-semiotized residue - and perhaps the residue that resists is where feeling comes from. Heaney has reversed the work of semiosis, undone much of what we thought we knew about being human, showed it to us like it really is. To borrow Richard Wilbur's beautiful lines, Heaney's poem has sundered/ Things and things' selves for a second finding, lost / For a moment all that it touches back to wonder.

In the hands of someone like Heaney, poetry becomes a cognitive instrument. Which is why, I think, pre-conceptualized devices such as allegory and abstraction simply do not work for the twentieth-century reader. We expect poetry to operate with a truly maieutic force, allowing us to rediscover things on our own, forcing us into direct contact with a world unmediated by the pre-conceptualized. We want the poem to make us feel and understand from the ground up. Yes, we think when we read Seamus Heaney, it really is like that.

\title{
Reactivation and Appropriation : Writerly Strategies
}

To return to the problematics of translating medieval poetry, the only way to take the top off the modern reader's head is to produce a free-standing text - an undertaking which involves as much reading-in and writing-in as will be necessary to make the text one's own. If the poetry is not to get lost in the shuffle between the fifteenth and the twentieth centuries, the mediator who conveys poetry across language and time has to work heuristically, as a writer rather than as a replicator. 
There are, of course, illustrious precedents for this stance. Of Ezra Pound it has been said that :

he was able to make what he found in the ideograms so much his own [...] that his translation gives us, as can no other, a realization of how the Confucian books have survived dynasty after dynasty in defiance of the shifting conventions of preciosity and of "effects". Confucius after twenty-four centuries stirs Pound into speech; Pound after twenty-four centuries lends Confucius his voice. ... [Pound's translations] are interchanges of voice and personality with the dead. (Kenner, [1953] 1970 , p. 14)

A more recent and no less brilliant example is Christopher Logue's rewrite of the Patrocleia (Book 16 of the Iliad). Rather than going for the kind of Wedgwood-china imagery and diction run-of-the-mill translators fall into line with, Logue has worked in a resolutely contemporary idiom, with the sort of technique, diction and structures that would not be out of place in his own, direct poetry : there's absolutely no translating down, here. As Donald Carne-Ross points out, "Logue has kept Pound in mind, taking from him the variety of metrical effects, the abrupt changes of tone, the presentation of a scene in terms of sharp visual images, the occasional use of prose and other devices" (Carne-Ross, 1963, p. 53). Logue has been even more audacious with the manipulation of cultural props, using all sorts of anachronisms and "anatopisms" to get us inside the poem. He's pushed the impertinence as far as throwing in artifacts from contemporary Indian and ancient Chinese history, the rationale being that "Ancient Greece, for a good many people, has been staled by long cultural contact whereas in Chinese art and poetry, a relatively recent acquisition, "le passé revit à l'état neuf" (Carne-Ross, 1963, p. 56). And since it's impossible for the latter half of the twentieth century to subscribe to Homer's glorification of warfare, Logue has unhesitatingly reversed Homer's stance : his Patrocleia reads like a condemnation of war.

The result of all this in-your-face manipulation has been to let "the genie out of the bottle" (Came-Ross, 1963, p. 63). What Pound and Logue have in common, of course, is genius plus the willingness to appropriate : if you can't make the poem yours, you won't be able to make a poem. 


\section{Strategies for Reactivating the Poetry of Charles d'Orléans}

I'd like now to discuss specific writerly strategies for reactivating the poems of Charles d'Orléans in such a way as to make their poetry available to the non-specialist reader.

One of the more obvious strategies is to release the poems from their thetorical strictures : nothing, I would claim, is less moving for the twentieth-century reader than page after page of allegory, personification, formulaic imagery. (It's hard for me to even imagine the esthetic pleasure the medieval reader would have derived from the constant play on moralized places, semi-personified qualities and unpacked metaphors such as le dur lit d'Ennuieuse Pensee.) Worn thin by over-use, the rhetorical devices in these poems have become lexicalized, thus losing much of their ability to arouse feeling.

The visual register, too, needs to be renewed : centuries of restless semiosis have relegated much of Orléans's imagery to the realm of the already-seen. And having been captured by the visual lexicon, many of these images have lost their urgency. One of the more evident shortcomings of Richard Wilbur's translation is its faihure to revitalize this off-the-peg imagery : Stream, brook and silver fountain play, / And each upon itself bestows / $A$ spangled livery as it flows has nowhere near the truth value, for us, of Wilbur's own as a forest is changed / by a chameleon's tuning his skin to it; / as a mantis arranged / on a green leaf, grows / into it. My approach, in my two successive versions of the same rondel, was to go for the one-of-a-kind image, so as to put my reader smack in the middle of an actual April and make him feel it on his skin, the marvel of being alive on a bright spring day :

version 1

(transl. B.F.)

The year has taken off its cloak of crackling cold and shivery, slipped on a rich embroidery of sunshine leaping like a spark.

There's not a plover, dove or shrike that doesn't whistle, shrill or cry version 2

(transl. B.F.)

The year has taken off its cloak of shivery winds and crackling colds, and draped itself in shifting folds of sunshine fitful as a spark.

Plover and robin, dove and blackbird - every living thing exults : 
"The year has taken off its cloak!"

Fountains and streams, warmed to

put on flamboyant finery,

[the quick,

all silver drops and filigree.

Lovers wear robes of scarlet silk :

the year has taken off its cloak.
"The year has taken off its cloak!"

Rivers and streams and fountains

[wake

to sounds of yellow in the fields

teeming with boisterous marigolds.

The heart pavanes in scarlet silk :

the year has taken off its cloak.

It would have been easy to replicate Orléans's imagery, as I did in the earlier version - Fountains and streams, warmed to the quick, / put on flamboyant finery, / all silver drops and filigree - but imagery like that is so lexicalized by now that it says precious little; all it adds to a purely denotational formulation are the connotations "fancy" and "would-be literary". I wanted to enact the marvel, so I wrote, in the second and final version : Rivers and streams and fountains wake / to sounds of yellow in the fields / teeming with boisterous marigolds.

But perhaps the most fundamental strategy for reactivating these poems is what $I$ refer to as the whole-corpus approach. Taken individually, the topoi themselves are no longer capable of moving us. What does convey meaning is the way the topol shift and darken as one moves through the corpus. We sense, in the way Charles d'Orleans has invested the sum total of these artificial figures, an authenticity and a particularity that we can "relate to". It's this darkening that gives us a way into the corpus, from April to winter, from rejoicing to melancholy, lassitude, acedia. Each poem becomes an instant in the trajectory of a man aging (Albert Pauphilet's mélancolies d'homme vieillisant).

The entire arc informs the rendering of each individual piece, and each individual image. Seeing the corpus as a curve from rejoicing and being young to melancholy and indifference is the most effective way of renewing the image fields. It allows the target-language poet to write in her own particular ways of rejoicing or lapsing into acedia, to embody marvel and melancholy the way they come to us in the twentieth century. A [Nonchaloir] m'abutineray; Trouvé l'ay plus prochain voisin, can get rendered by Betrayal, loss, acedia, rage / have wormed me through, I'm paper-thin (my rendering, in Folkart, forthcoming). We can move from le dur lit d'Enmuyeuse Pensee to contemporary ways of articulating the same distress : entropy, the wearing down of all things, the world thinning 
and whitening. From the vantage point of the entire corpus, we can attempt to find new images to trigger rejoicing and melancholy in a twentieth-century reader.

And finally, if these poems are to convey feeling, it's important to reactivate their form, as well as their stances and imagery, so that the form won't be perceived as something the reader has to make allowances for. Prosodic technique has to be updated : I've used slant mymes, preferentially, and deliberately set up some rather jarring enjambements to defeat the singsongy effect of the iambic fours. Surely part of the "value added" by the derived poem should be the tension between the constraints of the medieval form and the contemporary feel of the prosody in which the form is actualized.

Looking at my own translations, after the fact, I see them as having been written out of a visceral and imaginative engagement with very specific segments of the source-poems. In every case I seem to have re-enacted one central concrete image, which spoke to me (who knows why), gave me an immediate desire to write it, and thus "seeded" a new poem in English. If a poem didn't "click" in this way, I didn't attempt to translate it, because I couldn't make it mine - after all, no one was forcing me to translate the entire corpus. The initial "coup de coeur" was of course followed by a good deal of work : poems seldom write themselves holus-bolus. In the process, whole chunks of the original sometimes got discarded or twisted. I made every effort to intensify my texts, get rid of anything that would sound prosy in modern English, centre the new poem I was making around imagery and emotion.

The whole process is exemplified by the poems I derived from Balades 66 and $72^{3}$. Balade 66 is quite a concrete poem. My rendering of it was seeded by the sounds of the birds and by the first two lines, which gave me images of cold, snow and brilliant light, the rich, red, heart-shaped connotations of the name Valentin. I've worked the birds into the February landscape and tried to play these images off against the lethargy and acedia into which I've pushed ("outré") Orléans's ${ }^{3}$ The numbering here is that of Jean-Claude Muhlethaler's edition (Paris, Livre
de Poche, 1992). 
Nonchaloir, omnipresent in the latter part of the corpus :

Le beau souleil, le jour saint Valentin, Valentine's day, winter sun, Qui apportoit sa chandelle alumee, the world all February freeze :

N'a pas longtemps entra un bien matin the morning light comes swarming in, Priveement en ma chambre fermee. boistering through the draperies, Celle clarte qu'il avoit apportee, Si m'esveilla du somme de soussy Ou j'avoye toute la nuit dormy but I'm bogged down in the voiceless [stuff

of loss and lack, the void my life

Sur le dur lit d'ennuieuse pensee. drains into as I sleep alone.

Ce jour aussi, pour partir leur butin Des biens d'Amours, faisoient [assemblee

Tous les oyseaulx qui, parlans leur [latin,

Crioyent fort, demandans la livree Que Nature leur avoit ordonnee : C'estoit d'un per comme chascun [choisy.

Si ne me peu rendormir, pour leur cry. Sur le dur lit d'ennuieuse pensee.

Lors en moillant de larmes mon [coessin

Je regrettay ma dure destinee, Disant : : Oyseaulx, je vous voy en [chemin

De tout plaisir et joye desiree. Chascun de vous a per qui lui agree, Et point n'en ay, car Mort, qui m'a [trahy, A prins mon per dont en deuil je [languy

Sur le dur lit d'ennuieuse pensee.*
Outside, a flock of winter-thin starlings jostles in the trees. They shrill and chatter - there to dun the Saint in rasping starlingese for mates with whom to play at love. Their raucous hope flays me alive on the narrow bed where I sleep alone.

Love's feast! yet hair-brained destiny's so long on spite and short on plan that such mere flimsy fripperies as birds no wiser than a stone get mates, as sure as lindens leaf and I'm left mourning a dead love on the bare hard bed where I sleep alone.

Saint Valentin choisissent ceste annee Ceux et celles de l'amoureux party. So let them flock to Saint Valentine, those who still have the heart to believe : Seul me tendray, de confort desgarny, I'll keep to myself, sleep with my grief Sur le dur lit d'ennuieuse pensee. on the hard bare bed of all-alone.

I worked to slash through the allegorical busyness (le somme de soussy, le dur lit d'ennuieuse pensee), to try and create a sense of the instant - 
the brightness of a winter's day insulting the inner hurt of the speaking persona, a stance which is itself a topos, but one which still seems viable (cf. Baudelaire and beyond : j'ai puni sur une fleur l'insolence de la nature).

My main difficulty was dealing with the allusion to the lady's death $-a$ theme which must have resonated in the gut of the medieval reader but is so far out of our common experience that it appears to be a topos. This wasn't a grief I could make mine, and my inclination was to shy away from it : more than anything, I wanted to avoid bloating it into the melodrama of a Victorian parlour song. I've done what I could to keep the poem at the level of the winter and the winter birds, but I think the very presence of the death-theme - however understated - betrays the mixed origins of my poem.

Prosodically speaking, I kept the regular thyme scheme, which I actualized with slant rhymes, but cut the 8-line stanzas back to just 7 lines. Another strategy I used to make the fixed form new consisted of playing on the refrain line, which becomes increasingly formulaic as we move through the poem, until, at the very end of the envoi, with the cold hard bed of all-alone, it becomes one of those "réifications" Jean-Claude Muhlethaler speaks of $(1992$, p. 729).

Similar strategies came into play when I translated Balade 72 :

Charles d'Orléans,

(Mühlethaler, Balade 72)

Balades, chançons et complaintes

Sont pour moy mises en oubly,

Car ennuy et pensees maintes

M'ont tenu long temps endorny.

Non pour tant, pour passer soussy,

Essaier vueil se je sauroye

Rimer ainsi que je souloye.

Au meins j'en feray mon povoir,
Language growing old / Fruiting (tr. B.F.)

The poems that I used to make rondels and songs and vilanelles have silenced as my life has lapsed. Time has thinned me, I have lost the succulent, sap-filled words I used when language and the world were [ young.

And those who knew me poeming

${ }^{4}$ This needs qualifying. With the AIDS epidemic, and poets like Mark Doty, the death of the lover is again d'actualité, albeit with a different set of emotional, intellectual and visual resonances. 
Combien que je congnois et sçay

Que mon langage trouveray

Tout enroillié de nonchaloir.

Plaisans parolles sont estaintes

En moy qui deviens rassoty;

$\mathrm{Au}$ fort, je vendray aux attaintes,

Quant beau parler m'aura failly;

Pour quoy pry ceulx qui m'ont oy

Langagier, quant pieça j'estoye

Jeune, nouvel et plain de joye, que vueillent excusé m'avoir.

Oncques mais je ne me trouvay

Si rude, car je suis pour vray

Tout enroillié de nonchaloir.

Amoureux ont parolles paintes

Et langage frois et joly.

Plaisance, dont ilz sont accointes,

Parle pour eulx; en ce party

J'ay esté, or n'est plus ainsi.

Alors de beau parler trouvoye

A bon marchié tant que vouloye;

Si ay despendu mon savoir

Et, s'un peu espargnié en ay,

Il est, quant vendra a l'essay,

Tout enroillié de nonchaloir.

\section{L'envoy}

Mon jubile faire devroye, Mais on diroit que me rendroye Sans coup ferir, car bon Espoir M'a dit que renouvelleray :

Pour ce mon cueur fourbir feray Tout enroillié de nonchaloir. full-fleshed and rosy, flushed with joy, will see I've watered down my wine for language has grown grey and thin since I have passed the time for love.
People in love have radiant language, words like new leaves, or hyacinths opening to April rain :

they're spoken by their happiness.

So I was once : songs and songs came, effortless as willow catkins.

All that has changed : the power to leaf, the potency of root and bud and gravid branch has long since

$$
\text { [ waned - }
$$

the poems have faded in my mouth since I have ceased to fall in love.

Yet April's raw in the knurly vines, new tendrils form, I sense the sap creep in the elderly apple tree whose fruit won't stop till the day she [dies.

And I'll birth poems in September, though $I$ no longer fall in love.

Balade 72 is much "prosier" than Balade 66, so I cut it back far more severely, fusing the first two stanzas into a single one. The image that "seeded" my poem was provided by the first two lines of the original's 
third stanza : amoureux ont parolles paintes et langage frois et joly, which I turned into people in love have radiant language, words like new leaves, or hyacinths, opening to April rain. The contrast with Muthlethaler's glose speaks for itself :

Amoureux ont parolles paintes

Et langage frois et joly. parolles paintes : des paroles séduisantes Paintes renvoie à la conception des colores rhetorici, des figures du discours qui servent à «orner» la langue poétique

These lines, in turn, seeded the rest of my poem, which pivots about a single, extended image-field (a "trite-and-true" one, unfortunately vegetation as signifier of reproductive and creative vitality). I've feminized the image-field (the implicit image of the sword - tout enroillie de nonchaloir, sans coup ferir, pour ce mon cueur fourbir feray - is replaced by images of vegetation, and further feminized by the use of birth in the envoi) less as a deliberate strategy than a relapse into the stock of the already-said (this is of course one of the weaknesses of this piece).

I've taken liberties with the stance of the poem, in order to accentuate the downward curve (decline, loss of powers) which I find so important in the corpus overall. In particular, I've got rid of the over-redundant niceties about the rude engin that seems to have afflicted all medieval writers at one point or another. I've shifted the refrain out of the rust metaphor (trivial in modem English) and made the poem turn on the image of language itself aging; as with Orleans, there's a fusion of affective and creative aging. Formally speaking, my version of the piece is sporadically rhymed, and once again in iambic tetrametre, though the enjambements are significantly less "jarring" than in the Valentine's day Ballade.

\section{Conclusion}

Clearly, my renderings cannot be considered to "represent" the medieval poems for the modern reader. They are at best derived poems, conveying my own reactions to the most fleeting aspects of Orleans's poetry, and they're only as good as my skill at writing poetry. One might well ask why a reader would want to bother with idiosyncratic readings-in when he can read a less appropriative verse or prose translation that at least tries 
to leave the denotations and the image-fields intact. I could try to fudge the question by pointing out that even the ostensibly "faithful" rendering will always be a reading-in, that my poems are at least up-front about the subjective component I've introduced, that even the most pedestrian translation will bear the imprint of its translator. I could repeat my claim that poetry without the poetry is perhaps the biggest betrayal of all. All of which would be perfectly true. But I prefer to meet the question head on. The only justification for a derived poem, the criterion on which it must stand or fall is : how well does it work as a poem? Philip Hobsbaum has defined poetry as the patterns of an interesting mind made palpable (Hobsbaum, 1995, p. 58). Only if the reader can perceive in a derived poem, superimposed upon the vision of Charles d'Orléans, the patterns of a sufficiently interesting mind will reading it be worth his while. Marianne Moore's translations of La Fontaine pass the test with flying colours : one senses in them "the pleasuring of two poets three hundred years apart" (Folkart, 1993, p. xxi). But it's beyond a doubt that an awful lot of translation reveals the uninteresting patterns of truly uninteresting minds.

My own translations fall somewhere in between. None of the ones included in this essay really meet the criterion of being free-standing poems. I've kept too much of the originals' stance and imagery, haven't had the imagination or the guts to appropriate as much as I should have, bogged down halfway between Orléans's imagery and my own phantasms. As a result, no one would take these for original poems written in the twentieth century. The only one of these pieces that comes close to being successful is the rondeau - probably because hearing my daughter recite it as a little girl has given me an authentic way into its radiance.

Let me conclude with a couple of remarks on what the translation of medieval poetry has to tell us about translation in general and poetry in general. The approach I've been suggesting is meant to address the feelings of incompleteness and dissatisfaction a reader like me feels when confronted with the entire corpus of Charles d'Orléans. But no translation will ever substitute for reading these poems in the original, and for reading into the gaps of the original with the emotional and cultural competency a gifted philologist may have acquired over a life-time of working with medieval texts and artifacts. Then again, as I've claimed 
elsewhere, the only way to read any literary text with complete authenticity is to read it in the language of origin, preferably in the time and place of origin (Folkart, 1993, p. xxii). Certain losses we simply have to live with.

Each of the modes of translation I've referred to in the previous pages - the mimetic as well as the non-mimetic - has its own raison d'être : as a tool for learning Anglo-Saxon, I'd much rather have a close crib than a recreation like Pound's "Seafarer". Each of these approaches has its own, peculiar validity. All of them are more or less radically incomplete. The question of which form of translation to prefer merely sends us back to the most crucial observation of all : whereas the original poem gave it all to us, swiftly, compactly, forcefully, it takes a multitude of translations (complete with critical apparatus) to approximate the sum of the original parts - the grain of the text, its denotations, something of its imagery, its prosody, something like its poetry - and the sum of these translational approximations is almost inevitably less than the whole.

Nothing demonstrates the difference between writing and re-writing quite as powerfully as the impossibility of putting a poem "back together again" : the loss of ordering in a translation that sets out to replicate is of pretty much the same order of magnitude as the increase in entropy when Humpty-Dumpty splatters off his wall. It takes a whole spectrum of translations - from the crib to the verse replica - to even begin to approximate what the source-poem was. And even then, the deficit is enormous, and irreversible. All the translators in the world, with all the dictionaries and all the trots in all the librairies, will never put it back together again. All the more reason, perhaps, to just go ahead and write your own poem.

University of Ottawa

\section{References}

BRAULT, Jacques (1977). "Remarques sur la traduction de la poésie", Ellipse, 21, pp. 10-35. 
CARNE-ROSS, D.S. (1963). "Structural Translation", postscript to Christopher Logue's Patrocleia, Ann Arbor, University of Michigan Press, pp. 51-63.

FOLKART, Barbara (1993). "Modes of writing : translation as replication or invention?", plenary address to the fifth annual Purdue University Conference on Romance Languages, Literatures and Film (Romance Languages Annual, 5, pp. xv-xxii).

FOLKART, Barbara (forthcoming). "The poem as unit of translation : fixed-form renderings of Apollinaire and Charles d'Orléans".

HEANEY, Seamus (1990). New and Selected Poems 1966-1987, London, Faber and Faber.

HOBSBAUM, Philip (1995). "Growing like coral among shadows' : literary life respectable", Thumbscrew 3, pp. 53-61.

KENNER, Hugh, ed. ([1953]1970). The Translations of Ezra Pound, London, Faber and Faber.

LOGUE, Christopher (1963). Patrocleia of Homer, Ann Arbor, The University of Michigan Press.

MUHLETHALER, Jean-Claude, éd. (1992). Ballades et rondeazx de Charles d'Orléans, Paris, Livre de Poche.

ABSTRACT : Inventing the Past : Remarks on the Re-enactment of Medieval Poetry - No matter how qualified she may be from the philological standpoint, the translator of medieval poetry is immediately confronted with a sense of her own diachronic incompetence insofar as the cultural, esthetic and affective resonances of the medieval poem are concemed.

The translator who chooses to produce a crib will give the modem reader a way into the surface structures of the medieval text, but will convey little of its emotional resonance. Opting for prose translation will allow her to flesh her reading out somewhat, but convey none of the meaning inherent in the form itself. Even verse translation - if it remains merely verse - will prove inadequate to the "poetry" of the original text. 
The only way to give the twentieth-century reader a way into the jouissance of the medieval poem, as opposed to its syntax and semantics, is to function as a poet, and produce a free-standing text.

This essay discusses various writerly strategies for reactivating the poetry of the medieval poem, for producing feeling, and the sort of insight that can come only from feeling. Illustrating these considerations are a number of "derived poems" of my own, based on pieces by Charles d'Orléans.

RÉSUMÉ : Inventer le passé : remarques sur la réactivation de la poésie médiévale - Quelles que puissent être par ailleurs ses compétences de médiéviste, la traductrice de poésie ancienne demeure coupée, radicalement, de la matrice culturelle et pragmatique qui a informé aussi bien la réception que la production de ces textes.

Il existe, bien entendu, toute une panoplie d'approches traductionnelles - inadéquates, pour la plupart. La traduction-glose met en évidence le * grain * du texte, ses micro-structures linguistiques, mais passe à côté de ses contenus esthétiques et affectifs, comme de ses résonances culturelles. La traduction en prose foumit une meilleure approximation des contenus immédiats, mais escamote le sens véhiculé par la forme même. Même la traduction en vers peut passer à côté de la poésie du poème. Seule la traduction qui constitue en elle-même un poème aura quelques chances de procurer au lecteur cette jouissance esthétique et affective sans laquelle il n'est pas d'expérience poétique.

Cet essai fait état d'un certain nombre de stratégies artistiques visant à * réactiver $"$, pour le lecteur du vingtième siècle, quelque chose de la poésie et de la charge affective du poème médiéval. Mes réflexions sont illustrées par un certain nombre de * poèmes dérivés » que j'ai tirés moi-même de l'cuvre de Charles d'Orléans.

Barbara Folkart : School of Translation and Interpretation, University of Ottawa, C. P. 450, Succursale A, Ottawa (Ontario), K1N 6N5. Courriel : bfolkart@uottawa.ca 